to freedom and to work. No compulsion being exercised, no legislation was necessary. This is as it should be. There are very serious objections to compulsory sterilisation.

This discussion has made it clear not only that it is desirable (let me repeat) to cultivate the dry light of intelligence, but also that an extended knowledge of the elementary facts of sexual physiology and psychology would be highly advantageous. Here we see a medical man who apparently confuses vasectomy with castration; there another who believes that vasectomy is fairly comparable with cryptorchidism; again a third who, one suspects, imagines that $s^{+}$erilisation involves impotence. It is also evident that some among us, however young in years, are still living in the past, not realising what men and women are thinking and doing to-day, nor the new ideals which are inspiring them.

In these matters of eugenics the growth of both general and professional opinion (even since the Royal Commission on the Feeble-minded issued its report three years ago) is most remarkable to those who watch the development of opinion. It is idle to ignore it.

I am, Sir, yours faithfully,

West Drayton, Sept. 4th, 1911.

H. HAVELOCK ELLIS.

\section{NATIVE NURSES IN SOUTH AFRICA.}

To the Editor of THE LANOET.

SIR,-In a South African newspaper, the East London Daily Dispatch, a few weeks ago there appeared an extract from a letter said to have been published in THE LANCET. I have not been able to trace the letter in your columns, but as I presume it must have appeared I should be glad to be allowed a little space to reply to it. The writer says that the native probationers in training in this hospital "are stated to compare very unfavourably with European probationers," and the inference from his letter is that they are so unsatisfactory that no hospital will employ them. The fact, however, is that with one exception the colonial hospital authorities have never been willing to give these rurses a trial. That one hospital has employed two and is now wanting another.

It is quite true that a native girl has a longer hill to climb than a European girl before she can become a good nurse. Her home training usually is not so good. Studying in English is also a difficulty for probationers whose home language is not English. But some of our probationers have become very fair nurses, and in the work of nursing natives they, of course, have a great advantage over European nurses, who often cannot speak the patient's language. We are hoping to find employment for our native nurses under Lady Gladstone's District Nursing Scheme in memory of King Edward. In this scheme special provision is being made for this purpose, and I hope none of your South African readers who may be in a position to forward the native section of the scheme will be deterred from doing so by the letter to which I have referred. One of our nurses has for several years been engaged in district nursing and her work has been favourably commented upon both by her employers (a colliery company) and by the public health authorities. - I am, Sir, yours faithfully,

NeIr Macvicar, M.D.,

Medical Superintendent, Vietoria Hospital, Lovedale Mission, South Africa.

** The subject was referred to in our columns cn July 8 th, but the words quoted were not used. We have pleasure in publishing Dr. Macvicar's letter.-ED. L.

\section{TATTOOING $v$. VACCINATION.}

\section{To the Editor of THE LANCET.}

SIR, - Curiously enough, I was just on the point of writing to you on the subject of tattooing in connexion with vaccina. tion, when I read the letter of your correspondent, "E. A. A.," on the subject in Trre LANCET of August 26th, p. 664. My object was to tell you that I had recently been informed by a time expired non-commissioned officer, late of the Indian army, that at several stations where he had served medical officers repeatedly told the men that they need not be vaccinated if they were tattooed, and he himself being well tattooed had been exempted from compulsory vaccination.

The attention you are drawing to the subject ought to test the truth of such stories (personally I have absolute confidence in the trath of $\mathrm{my}$ informant) and bring the matter to the attention of those responsible. My informant added that men who agreed to allow themselves to be tattooed were granted 13 or 18 days (I forget which) relief from duty for the express purpose!

$$
\text { I am, Sir, yours faithfully, }
$$

J. Y. W. MACALISTER.

Royal Society of Medicine, Cavendish-square, W., August 31st, 1911.

\section{SYONTANEOUS COMBUSTION OF METHYLATED SPIRI'T.}

To the Editor of THE LANCET.

SIR,-With reference to the letter of Dr. John J. Robertson, in THE LANCET of August 12th, p. 475, may I record a somewhat similar incident that has occurred here? On August 1st a lady rose to make a cup of tea at $6.15 \mathrm{~A} . \mathrm{M}$. The spirit lamp (with wick) was standing on the floor near the grate. Directly she took the cover off it flared up, and she was burned rather severely about her face and ear. The lamp had not been used since the morning before. A box of matches was on the mantel-piece, but had not been touched. The window was open top and bottcm, but the sunlight was streaming through the glass on to the lamp. The patient told me that a similar accident happened ten years ago to her cousin. The lamp in that case was standing in a bay-window, and its ignition was attributed to the sunlight.

I am, Sir, yours faithfully,

W. J. ERNELY SuMPter, M.D., \&c.

Sheringham, August 29th, 1911

\section{A DERMOID CYST OF THE TESTICLE.}

To the Editor of THE LANCET.

SIR,-Dr. Frnest E. Hughes's statement, in recording a case with the above title in last week's number of THE LANCET, that " a left-sided testicular dermoid has yet to be recorded," presumably means in English. Of the cases collected by Wilms and published in 1896, the side affected was stated in ten cases and was the left in four of them. I am, Sir, yours faithfully, F. J. F. BARRINGTON

Medical School, University College Hospital, W.C. Sept. 4th, 1911

\section{A DISCOVERY IN REGARD TO THE FUNCTIONS OF THE KIDNEY : A CORRECTION.}

\section{To the Editor of THE LANCET.}

SIR,--I trust you will allow me to correct an error in the Croonian lecture delivered before the Royal Society on June 15 th by Professor T. G. Brodie, which I have only just noticed.

The "new conception of the glomerulus" of the kidney offered by Professor Brodie was discovered over 30 years ago $b_{7}$ my brother, Dr. A. W. Smyth of New Orleans (better known in connexion with the first successful operation for subclavian aneurysm by tying the vertebral artery for the first time, and mentioned at length in Erichsen's Surgery and by Sir Frederick Treves and others). The discovery in regard to the function of the kidney was published in a pamphlet at the time and appears in the "American Encyclopædia of Biography" and elsewhere.

A. W. Smyth showed that there was no communication between the Malpighian corpuscle and the uriniferous tubules, as taught by Bowman ; that there was no filtration that the water reached the tubules by their own epithelial cells ; that the glomerule was a vascular hydraulic ram acting with such force, as in one instance, to push a calculus half an inch in diameter down a ureter. I am, Sir, yours faithfully,

Maidstone, Sept. 1st, 1911.
WM. WOODS SMYTH Fell. Med. Soc. Lond, \&c. 